\title{
Potency of Green Cincau Leaves (Premna oblogifolia merr) Juice as Prebiotics and its Effect on Laying Hen Performances
}

\author{
Anna Lidiyawati $^{1 *}$, Eko Widodo $^{2}$, Edhy Sudjarwo $^{3}$ \\ ${ }^{1}$ Master Program of Animal Husbandry, Faculty of Animal Husbandry, University of Brawijaya, Malang, Indonesia \\ ${ }^{2}$ Department of Feed and Animal Nutrition, Faculty of Animal Husbandry, University of Brawijaya, Malang, Indonesia \\ ${ }^{3}$ Department of Animal Production, Faculty of Animal Husbandry, University of Brawijaya, Malang, Indonesia
}

\begin{abstract}
This study investigated the potency of green cincau leaves (Premna oblongifolia merr) juice as prebiotics end its effect on laying performances (feed intake, egg weight, feed conversion and hen day production) based on $\mathrm{pH}$ and digestive viscosity. The potency of green cincau leaves juice as prebiotic was tested. The result showed that green cincau leaves juice was effectively support growth of Lactic Acid Bacteria (LAB) with $4.3 \times 10^{2} \mathrm{CFU} . \mathrm{g}^{-1}$ samples but did not support the growth of Escherichia coli. The effect of green cincau leaves juice on laying performances was examined. Two hundred fifty 56-wk-old Hisex Brown layers received different diets namely 0, 5, 7.5, 10 and $12.5 \mathrm{ml}$ of green cincau leaves juice added in the basal feed. The method used in this study was experiment based on Completely Randomized Design and followed by Duncan's Multiple test if significant effect occurs. The result showed that increase level of $P$. oblongifolia merr in feed did not significantly affect $(P>0.05)$ feed intake, egg weight, feed conversion and hen day production.
\end{abstract}

Keywords: feed additives, laying hens performance, prebiotic, Premna oblongifolia merr juice.

\section{INTRODUCTION}

Fiber is one of important component in diet which gives beneficial effect to the development of gastrointestinal tract and, therefore, performance in monogastrics. Green cincau leaf (Premna oblongifolia merr) which contains soluble and insoluble fibers, could be promoted to manipulate the digestive physiological function. The soluble fiber optimizes growth of anaerobic bacteria which modifies and/or changes villous characteristics [1]. Insoluble fiber, on the other hand, increases retention time of the digesta in upper part of digestive tract (crop to gizzard) and gizzard function. The soluble fiber of green cincau leaf consist of mostly hemiselulose and pectin. While the insoluble fiber contents are selulosa, lignin and silica. The ratio of insoluble to soluble fiber is important for more efficient production [2].

The use of plant phytogenics has been found to be a good candidate to replace antibiotics. Antibiotics are used to treat specific health problems (therapeutic use) and to improve the animal performances (growth promoter use). This practical use of antibiotics has been avoided due to the development of antibiotic-resistant

\footnotetext{
* Correspondence author: Anna Lidiyawati

Email : anna_lidiyawati@ymail.com

Address : Faculty of Animal Husbandry, University of Brawijaya, Jl. Veteran Malang, 65145
}

strains of bacteria that contribute to the presence of antibiotic-resistant pathogens in humans. Previous report indicated that aqueous extract of green cincau leaf (Cyclea barbatas merr) $3 \mathrm{~mL}^{- \text {day }^{-1}}$ in rats did not affect on the acetylsalicylic acid-induced gastric acid, but it showed protective effect againts acetylsalicylic acid induced gastric mucosal lession [3], and green cincau leaf ( $P$. oblongifolia merr) extract of $5.4 \mathrm{~mL}$ day $^{-1}$ significantly decreased trigycerides of Sprague Dawley rats dyslipidemia for about $18 \%$ [4]. The current research was intended to examine effect of added various level of green cincau juice in diets on laying hen performances and digesta characteristics (TPC for Lactic acid bacteria and Escherichia coli, $\mathrm{pH}$ and viscosity), and performances.

\section{MATERIALS AND METHODS}

\section{Preparation of Premna oblongifolia merr juice}

Total $10 \mathrm{~g}$ of selected leaves of $P$. oblongifolia merr plant were mixed with $250 \mathrm{ml}$ of water, stirred the mixture by using a medium speed (250 rpm for 1 minute) of kitchen blender. The results were then filtered by using muslin cloth.

\section{Chemical analysis}

Analysis of soluble fiber was by gravimetric method and pectin analysis was by Bayes method. Crude fiber was analyzed by using Van Soest method [5]. 


\section{Microbial analysis}

MRSA were used for isolation of Lactic Acid Bacteria, and EM agar for E. coli. The total plate count lactic acid bacteria and $E$. coli were counted after incubation in aerobic chamber at $37^{\circ} \mathrm{C}$ for 48 hours with colony counter [6].

\section{Bird and Diet}

A total 250 fifty-six-weeks old laying hens were used in this experimentand randomly alloted to 5 treatments and 5 replications, 10 hens for each replication. The addition of different levels of $P$. oblongifolia merrj uices into the basal diet were arranged into 5 treatments (Table 1 ).

Table 1. Diet for the Hens

\begin{tabular}{ccc} 
& \multicolumn{2}{c}{ Table 1. Diet for the Hens } \\
\hline Treatments & Basal diet & $\begin{array}{c}\text { Green cincau leaves extract } \\
\text { (ml.bird }{ }^{-1} \text {.day }{ }^{-1} \text { ) }\end{array}$ \\
\hline$P_{0}$ & $V$ & - \\
$P_{1}$ & $V$ & 5.0 \\
$P_{2}$ & $V$ & 7.5 \\
$P_{3}$ & $V$ & 10.0 \\
$P_{4}$ & $V$ & 12.5 \\
\hline
\end{tabular}

The basal diet (Table 2 and 3) was formulated to meet the layer chicken requirements (Table 4) based on SNI [7]. The layer chicken had free access to feed and water. Basal Diet was analyzed in Feed and Nutrition laboratory Facuty of Animal Husbandry-UB.

\begin{tabular}{lc} 
& Table 2. Formula of Basal Diet \\
\hline Ingredients & Total (\%) \\
\hline Corn grain & 50.51 \\
Rice bran & 15.78 \\
Concentrate & 31.57 \\
Mineral & 1.89 \\
Premix & 0.25 \\
\hline
\end{tabular}

Table 3. Chemical composition of dietary ingredients

\begin{tabular}{|c|c|c|c|}
\hline Ingredients (\%) & $\begin{array}{c}\text { Corn } \\
\text { grain }^{[8]}\end{array}$ & $\begin{array}{c}\text { Rice } \\
\text { bran }^{[8]}\end{array}$ & $\begin{array}{l}\text { concen- } \\
\text { trate }^{[9]}\end{array}$ \\
\hline Crude Protein & 8.50 & 12.20 & 36.00 \\
\hline Crude Fat & 3.80 & 11.00 & 5.00 \\
\hline Crude Fiber & 2.20 & 4.10 & 8.00 \\
\hline Ash & 1.50 & 6.90 & 35.00 \\
\hline Calcium & 0.02 & 0.05 & 11.00 \\
\hline Total Phosphorus & 0.28 & 1.31 & 1.00 \\
\hline
\end{tabular}

Table 4. Basal Diet and Standard Quality of Layer Feed

\begin{tabular}{lcc}
\hline \multicolumn{1}{c}{ Ingredients } & $\begin{array}{c}\text { Basal } \\
\text { Diet }\end{array}$ & $\begin{array}{c}\text { Layer Feed } \\
\text { Standard }\end{array}$ \\
\hline ME (Kkal.kg ${ }^{-1}$ ) & $2780^{*}$ & $>2650$ \\
Crude Protein (\%) & 18.02 & $17.2-18.2$ \\
Crude Fat (\%) & 5.16 & $<7.0$ \\
Crude Fiber (\%) & 4.36 & $<7.0$ \\
Ash (\%) & 13.41 & 14 \\
Calcium (\%) & 3.68 & $3.25-4.25$ \\
Total Phosphorus (\%) & 0.66 & $0.6-1.0$ \\
\hline$*$ Estimating Metabolizable Energy (ME) as $70 \%$ of Gross \\
Energy (GE)
\end{tabular}

\section{Sample}

On 60 weeks old, one bird was randomily selected from each replication cage and was killed by cervical dislocation and immediately after that intestinal sample in the section between meckel diverticulum and ileocaecal junction was collected. The digesta of all above mentioned segment was then immediately brought to laboratory for microbial study.

\section{Performance parameter}

Bird performance was evaluated through the average egg production within 60 days, in percentage per bird per day. It was obtained from the number of eggs produced, including cracked, broken or abnormal, and the number of birds per plot that produced them, the average egg weight at the end of each experimental week through the intact eggs collected during the day in each plot and weighed.

Feed intake: Food intake in grams consumed per bird per day.

Egg weight: The product of egg production and the average egg weight in grams.

Feed conversion: The average feed intake $(\mathrm{kg})$ by the average eggs mass produced (egg weight, kg $x$ egg production. $100^{-1}$ ) expressed in kilograms of feed consumed per kilogram of egg production.

Hen-Day Production (HDP): Ratio between numbers of eggs on daily basis to number of bird available in the flock on that day $x 100 \%$.

\section{pH and Viscosity of The Digesta}

Digesta $\mathrm{pH}$ was then measured within using a digestive $\mathrm{pH}$ meter method [10]. Digesta were dissected and polled in collection tube, intestine digesta viscosity was measured according to the method [10].

\section{Statistical Analysis}

Experiment based on Completely Randomized Design. It was followed by Duncan's multiple test if significant effect occurs.

\section{RESULT AND DISCUSSION Fiber Composition}

Green cincau leaves ( $P$. oblongifolia merr) juice contains soluble fiber and insoluble fiber. Table 5 showed the composition and the fiber composition in green cincau leaves. The $1 / 3$ of total fraction fiber was soluble fiber and $2 / 3$ was insoluble fiber. In Green cincau leaves juice soluble fiber was $0.62 \%$. The previous report indicated that leaves juice contained $1.94 \mathrm{~g}$ total 
fiber with $1.45 \mathrm{~g}$ insoluble fiber and $0.48 \mathrm{~g}$ soluble fiber [11].

Table 5. Fiber Composition in Green Cincau Leaves

\begin{tabular}{lc}
\hline Type of Fiber & Total (\%) \\
\hline Pectin & 0.55 \\
NDF & 67.68 \\
ADF & 54.51 \\
Hemiselulosa & 13.17 \\
Selulosa & 35.71 \\
\hline
\end{tabular}

\section{Microbial Population}

TPC of digesta for Lactic Acid Bacteria (LAB) and E. coli were presented in Table 6 and 7. The result showed $P$. oblongifolia merr juice was effectively support growth of Lactic Acid Bacteria (LAB) with $4.3 \times 10^{2}$ CFU.g ${ }^{-1}$ samples but did not support the growth of $E$. coli. Previous report showed that Green cincau gel forming agent extract has a prebiotic effect with total lactic acid bacteria $11.97 \times 10^{11}$ CFU.mL ${ }^{-11}$ [12]. Pectin in green cincau leaves juice was suspect as substrat to support growth of Lactic Acid Bacteria (LAB). Carbon chain in galacturonic acid is converted to VFA (Volatil Fatty Acid) and became substrat that support growth of Lactic Acid Bacteria [13] but did not support the growth of $E$. coli.

Table 6. Total Plate Count (TPC) Lactic Acid Bacteria

\begin{tabular}{|c|c|c|c|c|}
\hline \multirow{2}{*}{ dilution } & \multicolumn{2}{|c|}{ Total LAB } & \multirow{2}{*}{ median } & \multirow{2}{*}{$\begin{array}{c}\text { Total } \\
\text { (CFU.g }{ }^{-1} \text { sample) }\end{array}$} \\
\hline & I & II & & \\
\hline $10^{-1}$ & 48 & 37 & 42.5 & $4.3 \times 10^{2}$ \\
\hline $10^{-2}$ & 19 & 12 & 15.5 & \\
\hline $10^{-3}$ & 5 & 3 & 4.0 & \\
\hline
\end{tabular}

Table 7. TPC (Total Plate Count) Escherichia coli

\begin{tabular}{llllc}
\hline \multirow{2}{*}{ Dilution } & \multicolumn{2}{c}{ Total E.coli } & median & $\begin{array}{c}\text { Total } \\
\text { (CFU.g }\end{array}$ \\
\cline { 2 - 3 } & I & II & & 0 \\
\hline $10^{-1}$ & 0 & 0 & 0 & \\
$10^{-2}$ & 0 & 0 & 0 & \\
$10^{-3}$ & 0 & 0 & 0 & \\
\hline
\end{tabular}

\section{pH of the Digesta}

Table 8 showed that the addition of 12.5 $\mathrm{mL}$.bird. ${ }^{-1}$ day $^{-1}$ green cincau leaves juice in basal diet decreased $\mathrm{pH}$ of the digesta to 5.42 from 6.53 .

Table 8. pH and viscosity of digesta

\begin{tabular}{ccc}
\hline \multirow{2}{*}{ Treatment } & \multicolumn{2}{c}{ Indicator } \\
\cline { 2 - 3 } & $\mathbf{p H}$ & $\begin{array}{c}\text { Viscosity } \\
\text { Digesta(dPa.s) }\end{array}$ \\
\hline $\mathrm{P}_{0}$ & $6.53 \pm 0.07^{\mathrm{a}}$ & $0.34 \pm 0.02^{\mathrm{a}}$ \\
$\mathrm{P}_{1}$ & $6.24 \pm 0.04^{\mathrm{a}}$ & $0.29 \pm 0.02^{\mathrm{b}}$ \\
$\mathrm{P}_{2}$ & $5.94 \pm 0.06^{\mathrm{b}}$ & $0.22 \pm 0.02^{\mathrm{c}}$ \\
$\mathrm{P}_{3}$ & $5.56 \pm 0.07^{\mathrm{c}}$ & $0.14 \pm 0.01^{\mathrm{d}}$ \\
$\mathrm{P}_{4}$ & $5.53 \pm 0.13^{\mathrm{d}}$ & $0.08 \pm 0.01^{\mathrm{e}}$ \\
\hline
\end{tabular}

Description : diffrent superscript in the same column indicated significant effect $(P<0.01)$
Pectin in green cincau leaves juice could be fermented by microflora to short chain fatty acid (VFA) and some spesific microflora produced latic acid so that $\mathrm{pH}$ decreased and inhibit patogen bacteria [14]. Type of fiber (selulosa, oat hulls and sugar beet pulp) gives significant variation on $\mathrm{pH}$ digesta which sugar beet pulp gives lowest $\mathrm{pH}$ because of pectin content [15].

\section{Digesta Viscosity}

Decreased viscosity in treated bird than those given only basal diets indicated that pectin in green cincau leaves juice as soluble fibre was fermentable to support growth of anaerob bacteria. Increased viscosity was usually followed by increased population of anaerobic bacteria. The bacteria then increased SCFA (Short chain fatty acid) produced and affected in villous characteristic [16]. Supplementation of organic acid in the diet was capable to lowering digesta viscosity in laying hen [17]. Ratio of pectin dan selulosa affected differently on performance and phycochemical conditions of intestine [18].

\section{PERFORMANCE \\ Feed intake}

Green cincau leaves juice as additive in laying hens diets did not give significant effect on feed intake (Table 9). This indicated that fiber component in green cincau leaves juice can be tolerated by laying hens. The use of iso-protein and isoenergy in all diets used is also another factor that makes feed consumption remains unaffected. Basal diet formulated has crude protein of $18.02 \%$ and Metabolizable Energy of 2780 kcal. $\mathrm{kg}^{-1}$ was in accordance to recommendation of NRC [8]. Soluble fiber and insoluble fiber in green cincau leaves juice might also give no changes toward digestion physiology particularly on passage rate, so that feed intake did not significantly affected ( $P>0.05$ ) by the treatments.

\section{Egg weight}

Treatments with various level of green cincau leaves juice did not significantly affect egg weight (Table 9). This may largely due to the addition of additive in the basal diet did not change protein and energy contents and therefore also their intake. Fiber component in green cincau leaves juice was able to reduce $\mathrm{pH}$ and intestinal viscosity but such effects could not able to change digestibility of nutrient so that no egg weight was observed in this study. Previous study observed that suplementation of $6 \%$ Hazel nut hulls in layer diets affected in yolk and egg weights [19]. 
Tabel 9. Effect of Green Cincau Leaves Juice on Laying Hens Performance

\begin{tabular}{|c|c|c|c|c|}
\hline \multirow[b]{2}{*}{ Treatment } & \multicolumn{4}{|c|}{ Indicator } \\
\hline & $\begin{array}{l}\text { Feed in take } \\
\text { (g.bird. }^{-1} \text { day }^{-1} \text { ) }\end{array}$ & $\begin{array}{l}\text { Egg weight } \\
\text { (g.unit }^{-1} \text { ) }\end{array}$ & Feed conversion & HDP (\%) \\
\hline$P_{0}$ & $114.98 \pm 3.48$ & $67.43 \pm 0.59$ & $2.12 \pm 0.11$ & $87.32 \pm 1.64$ \\
\hline $\mathrm{P}_{1}$ & $114.83 \pm 1.81$ & $67.04 \pm 0.37$ & $2.01 \pm 0.03$ & $82.23 \pm 2.53$ \\
\hline $\mathrm{P}_{2}$ & $111.38 \pm 3.11$ & $67.71 \pm 0.78$ & $2.08 \pm 0.06$ & $81.31 \pm 6.24$ \\
\hline$P_{3}$ & $113.68 \pm 2.96$ & $67.33 \pm 1.25$ & $2.02 \pm 0.12$ & $85.61 \pm 5.34$ \\
\hline $\mathrm{P}_{4}$ & $113.54 \pm 0.75$ & $66.28 \pm 0.97$ & $2.04 \pm 0.11$ & $88.09 \pm 2.45$ \\
\hline
\end{tabular}

\section{Feed Conversion}

Green cincau leaves juice as additive in laying hens diets did not significantly affected to feed intake and egg weight, so that feed conversion ratio (Table 9). The potential effect green cincau leaves juice as prebiotics could not able to change the performances. A study observed that supple-mentation of prebiotics caused decresing feed conversion [20]. Feed coversion decrease in broiler (1-14 day) diet with added of pectin than CMC (Carboxymethyl cellulose) was also reported [21]. This study found that adverse effect of pectin might be eliminated by selulose content in green cincau leaves juice, so that feed conversion did not change.

\section{Hen Day Production}

On the basis of Hen day production no significant effect was observed (Table 9). Improvement GIT enviroment with lower $\mathrm{pH}$ and viscosity could not be able to increase nutrient digestion and absorption so that hen day production did not change.

\section{CONCLUSION}

Green cincau leaves ( $P$. oblongifolia merr) juice contained $0.62 \%$ soluble fiber majoring in pectin $(0.55 \%)$. It effectively support growth of Lactic Acid Bacteria (LAB) with $4.3 \times 10^{2} \mathrm{CFU}^{-1} \mathrm{~g}^{-1}$ sample but did not support the growth of E. coli. The used of green cincau leaves juice until 12.5 $\mathrm{mL}$.bird. ${ }^{-1}$ day $^{-1}$ in feed did not significantly affect $(P>0.05)$ the laying hen performances.

\section{Acknowledgement}

This research was funded by LPDP (Lembaga Pengelola Dana Keuangan) Ministry of Finance Republic of Indonesia.

\section{REFERENCES}

[1] Iji, P.A., R.J. Hughes., M. Choet, D.R. Tivey. 2001. Intestinal structure and function of broiler chickens on wheat-based diets supplemented with microbial enzym. AsianAustralian J. Animal Sci. 14. 54-60.
[2] Saki, A.A., H.R.H. Matin, M.M. Tabatabai, P. Zamani, R.N. Harsini. 2011. Various ratios of pectin and Cellulose affect intestinal morphology, DNA quantitation and performance of broiler chickens. Livest. Sci. 139. 237294.

[3] Djam'an, Q. 2008. The effect of aqueous green Cincau leaves (Cyclea barbatas merr) on acetylsalicylic acid-induced gastric acid and gastrohistopathology feature in rats. Master Thesis. Graduate Program of Biomedical Science. Diponegoro University.

[4] Wahyu, B. 2012. The difference in total cholesterol and triglyceride level before and after giving green cincau leaves (Premna oblongifolia merr) in rats dislipidemia. J. Nutr. Collage. 2(1). 118-125.

[5] Association of Official Analytical Chemist (AOAC). 1988. Official methods of analysis: AOAC. Arlington.

[6] Fardiaz, S. 1993. Analisa mikrobiologi pangan. PT. Raja Grafindo Persada. Jakarta.

[7] SNI. 1995. Standard Quality of Layer Feed. Indonesian National Standard.

[8] National Research Council (NRC). 1994. Nutrient requirement of poultry $9^{\text {th }}$ Rev Ed. National Academy Press.

[9] Cargill Indonesia. Leaflet layer concentrate of SLC (Super Layer Konsentrat) PT.Cargill. Pasuruan.

[10] Leeuwen, P. V., A.H. van Gelder, J.A.de Leeuw, J.D. van der Klis. 2006. An animal model to study digesta passage in different compartment of the Gastro Intestinal Tract (GIT) as affected by dietary composition. Current Nutr. Food Sci. 2(1). 97-10.

[11] Spiller, G.A. 2001. Dietary fiber in human nutrition $3^{\text {rd }}$ Ed. CRC Press LLC.

[12] Murhadi, U.N. Samsu, A. Dedy, Maryanti. 2009. Evaluation of laxative effect and fermentability of gel forming component of Green Cincau leaves. J. Ind. Tech. Agr. Prod. 14(2). 129-141.

[13] Dongowski, G., A. Lorenz, H. Anger. 2000. Microbiology degradation of pectins with 
differnt degrees of esterification by bacteroides thetaiotaomicron isolated from human gut flora. Appl. Environ. Microbiol. 66(4). 1321-1327.

[14] Montagne, L., Pluske, J.R., D.J. Hampson, 2003. A review of interactions between dietary fiber and the intestinal mucosa and their consequences on digestive health in young non-ruminant animals. Anim. Feed Sci. Tech. 108. 95-117.

[15] Jimenez-Moreno, E., J.M. GonzalezAlvarado, A. de Coca-Sinova. 2009. Effect of source of fibre on the development and $\mathrm{pH}$ of gastrointestinal tract of broilers. Anim. Feed Sci. Tech. 154. 93-101.

[16] Xu, Z.R., C.H Hu, M.S Xia, X.A. Zhan, M.Q. Wang. 2003. Effect of dietary fructooligosaccharide on digestive enzyme activities, intestinal microflora and morphology of male broilers. Poult. Sci. 82. 1030-1036.

[17] Ozek, K., K.T. Wellmann, B. Ertekin, B. Tarm. 2011. Effect of dietary herbal essential oil mixture and organic acid preparation on laying traits, gastrointestinal tract characteristics blood parameters and immune respone of laying hens in hot summer season. Anim. Feed Sci. Tech. 20. 575-586.

[18] Saki, A.A., H.R.H. Matin., M.M. Tabatabai, P. Zamani, F. Mirzaaghatabar. 2011. Non strach polysaccharides and broiler response. World Appl. Sci. J. 15(2). 192-198.

[19] Yalcin, S., I. Colpan, Sehu. 1990. The utilization of hazelnut hulls by laying hens. Vet. Fakultesi. Dergisi Univ. Ankara. 37(3). 485-498.

[20] Kompiang, I.P., M.H. Supriyati, Togatorop, S.N. Jarmans. 2001. The effect of free choice feeding on the performance of native chicken. J. Anim. Husbandry Vet. 6(2). 9499.

[21] Bidura, I.G.N.G., E. Puspani, D.A. Warmadewi, T.G.O. Yusila, I.W. Sudiastra. 2014. Effect of pollard fermented by yeast culture in diets to egg productin of Lohmann brown egg. Majalah IImiah Peternakan. 17(1). 4-9. 